\title{
Penentuan Penanganan Persalinan Caesar dengan Neural Network dan Particle Swarm Optimization
}

\author{
${ }^{1}$ Insan Cahya Setia*, ${ }^{2}$ Toni Arifin \\ ${ }^{1,2}$ Sistem Informasi, Teknologi Informasi, Universitas Adhirajasa Reswara Sanjaya \\ Jl. Sekolah Internasional No. 1-2, Bandung 40282, Indonesia \\ *e-mail: insancs@gmail.com
}

(received: 14 Januari 2021, revised: 5 Maret 2021,accepted: 7 April 2021)

\begin{abstract}
Abstrak
Persalinan caesar merupakan suatu tindakan operatif pada ibu bersalin dengan melakukan insisi pada kulit, dinding perut dan dinding rahim untuk menyelamatkan ibu serta bayi. Tindakan caesar dilakukan jika sang ibu tidak dapat melahirkan secara normal yang disebabkan oleh suatu indikasi tertentu. Untuk mengurangi resiko persalinan pada ibu dan bayi, perlu dilakukan pemeriksaan kondisi calon pasien caesar, maka dapat dilakukan penerapan dan pemanfaatan teknik data mining guna meminimalisir kesalahan dalam pemeriksaan. Klasifikasi yaitu salah satu poin penting dalam data mining atau pembelajaran mesin. Klasifikasi merupakan suatu pengelompokan data dimana data tersebut memiliki kelas label atau target. Salah satu metode data mining untuk masalah klasifikasi yang bisa implementasikan yaitu Neural Network. Untuk meningkatkan hasil akurasi penelitian, maka dapat digunakan pembobotan atribut menggunakan Particle Swarm Optimization. Pada penelitian yang dilakukan, teknik klasifikasi metode Neural Network dan Particle Swarm Optimization diterapkan pada Caesarian Section Classification Dataset. Setelah penelitian selesai dilakukan, diperoleh hasil akurasi menggunakan Neural Network mencapai $87.50 \%$ dengan nilai Area Under Curve (AUC) yaitu 1.000. Kemudian hasil akurasi menggunakan Neural Network berbasis Particle Swarm Optimization mengalami peningkatan sebesar 6.25\% dengan akurasi mencapai $93.75 \%$ dan Area Under Curve (AUC) yaitu 0.913 .
\end{abstract}

Kata kunci: Bobot, Klasifikasi, Neural Network, Particle Swarn Optimization, Penanganan Caesar

\begin{abstract}
Caesarean is an operative action on the mother by giving an incision in the skin, abdominal wall and uterine wall to save the mother and baby. Caesarean section is performed if the mother is unable to give birth normally due to a certain indication. To reduce the risk of childbirth to the mother and baby, it is necessary to examine the condition of prospective caesarean patients, so the application and utilization of data mining techniques can be done to minimize errors in the examination. Classification is one of the important points in data mining or machine learning. Classification is a grouping of data where the data has a label or target class. One of the data mining methods for classification problems that can be implemented is the Neural Network. To improve the results of research accuracy, attribute weighting can be used using Particle Swarm Optimization. In the research conducted, the classification technique of Neural Network method and Particle Swarm Optimization is applied to the Caesarian Section Classification dataset. After the research was completed, the accuracy of using the Neural Network was $87.50 \%$ with Area Under Curve (AUC) is 1.000. Then the accuracy of using Neural Network based on Particle Swarm Optimization has increased by $6.25 \%$ with an accuracy reaching $93.75 \%$ and Area Under Curve (AUC) is 0.913.
\end{abstract}

Keywords: Caesarian Section Delivery, Classification, Neural Network, Particle Swarn Optimization, Weight.

\section{Pendahuluan}

Organisasi Kesehatan Dunia (WHO) pada tahun 2017, menyatakan sekitar 296 ribu wanita mengalami kematian selama dan setelah kehamilan atau persalinan. Angka Kematian Ibu (AKI) global pada tahun 2017 diperkirakan mencapai 211 kematian ibu per 100 ribu kelahiran hidup [1]. Di 
Indonesia sendiri, pada tahun 2015 Angka Kematian Ibu (AKI) mencapai 305 per 100 ribu kelahiran [2]. Upaya dalam menurunkan Angka Kematian Ibu (AKI) terus diupayakan, salah satunya yaitu dengan persalinan secara caesar [3].

Persalinan yaitu proses pengeluaran hasil konsepsi (janin dan uri) dari uterus (rahim) melalui jalan lahir atau jalan lain [4]. Persalinan biasanya terjadi secara normal, namun pada beberapa kasus juga terdapat persalinan yang mengalami masalah dan secepatnya harus ditangani dengan jalan lain, salah satunya dengan operasi [5]. Dalam dunia kebidanan, persalinan terdiri dari dua metode, persalinan dengan metode caesar dan normal[6].

Persalinan caesar merupakan suatu tindakan operatif pada ibu bersalin dengan melakukan insisi pada kulit, dinding perut dan dinding rahim untuk menyelamatkan ibu serta bayi. Tindakan caesar dilakukan jika sang ibu tidak dapat melahirkan secara normal yang disebabkan oleh suatu indikasi tertentu [7]. Banyak faktor seorang ibu melahirkan secara caesar, misalnya plasenta previa, hipertensi, bayi sungsang, gawat janin, pinggul sempit, dan bisa juga mengalami pendarahan pada ibu sebelum tahap persalinan. Diharapkan lewat persalinan dengan metode caesar bisa meminimalis masalah pada bayi dan ibu [8].

Dalam perkembangan teknologi yang amat sangat pesat seperti saat ini, pemanfaatan teknologi informasi dapat kita temukan dalam berbagai bidang, salah satunya bidang kesehatan. Data Mining salah satu bidang yang dapat diterapkan dalam bidang kesehatan. Data Mining adalah metode yang digunakan untuk memperoleh ilmu pengetahuan dalam kumpulan data. Kumpulan data yang hanya tersimpan diolah sedemikian rupa dengan suatu teknik data mining dengan tujuan untuk menghasilkan suatu pola pengetahuan yang bisa digunakan bagi keperluan prediksi medis, dalam hal ini khususnya untuk menganalisis penentuan status penanganan proses persalinan sang ibu dan bayinya [9].

Neural Network merupakan salah satu dari sekian banyak algoritma data mining yang bisa digunakan untuk membuat prediksi data medis [10]. Neural Network adalah suatu konsep rekayasa pengetahuan dalam bidang kecerdasan buatan yang dirancang seperti syaraf pada manusia [11], seperti proses informasi pada otak manusia yang menghubungkan satu neuron ke neuron yang lain [12]. Neural Network sering disebut juga dengan Jaringan Syaraf Tiruan (JTS). Istilah tiruan digunakan karena dalam proses pembelajarannya jaringan syaraf ini perinspirasi dari cara kerja sistem syaraf pada manusia [13]. Dalam penerapan metode data mining dalam suatu penelitian terkadang masih memiliki nilai akurasi yang sangat rendah, maka dari itu perlu dilakukan suatu optimasi guna menghasilkan nilai akurasi terbaik [14].

Particle Swarm Optimization adalah suatu metode optimasi berbasis populasi yang dapat meningkatkan nilai akurasi sebuah metode [14]. Particle Swarm Optimization merupakan sebuah teknik optimasi yang terilhami dari perilaku burung dan ikan dalam mencari sumber makanan [15]. Ada dua konsep utama dalam Particle Swarm Optimization, yaitu kecepatan dan posisi untuk setiap partikel. Setiap partikel mempunyai kecepatan awal dan posisi dalam ruang solusi. Seiring dengan perkembanganya, partikel-partikel tersebut bertemu menuju posisi terbaik. Karena Particle Swarm Optimization cukup sederhana untuk diimplementasikan, Particle Swarm Optimization membutuhkan lebih sedikit memori dan tidak memiliki operator. Karena kesederhanaan ini, Particle Swarm Optimization juga adalah salah satu algoritma yang cepat [16].

Pada penelitian ini, penulis akan melakukan optimasi atribut untuk klasifikasi penentuan penanganan persalinan Caesar menggunakan Neural Network dan Particle Swarm Optimization. Dataset yang penulis gunakan adalah Caesarian Section Classification Dataset yang terdapat di UCI Machine Learning Repository. Age, Delivery number, Delivery time, Blood of Pressure, dan Heart Problem merupakan atribut-atribut yang akan dilakukan optimasi, yaitu optimasi bobot. Tujuan dari penelitian yang penulis lakukan yaitu guna mengetahui akurasi dari Neural Network juga mengetahui kenaikan akurasi dari Neural Network sesudah dilakukan optimasi dengan metode Particle Swarm Optimization untuk klasifikasi penentuan penanganan persalinan caesar.

\section{Tinjauan Literatur}

Penelitian tentang klasifikasi penentuan penanganan persalinan Caesar telah banyak dilakukan dengan metode yang beragam pada penelitian sebelumnya. Penelitian yang dilakukan oleh Shidiq et al., [3] bertujuan guna mengklasifikasi apakah harus menggunakan metode caesar atau tidak dalam 
proses persalinan, sehingga dapat memprediksi keselamatan ibu dan bayinya. Algoritma yang digunakan adalah Neural Network dengan model pengujian menggunakan cross validation dengan validasi 10 fold cross validation. Dari penelitian yang dilakukan dihasilkan nilai akurasi sebesar 71.25\% dengan AUC 0.721. Dari hasil yang didapat kemudian di evaluasi dan validasi menggunakan uji ROC Curve dan Confusion Matrix. Grafik ROC dengan nilai AUC 0.721 termasuk kategori "klasifikasi cukup/fair classification" karena rentang nilai antara $0.70-0.80$.

Penelitian yang dilakukan oleh Abdurrahman dan Wijaya [17] bertujuan untuk menetukan apakah kelahiran akan dilakukan secara normal atau diberikan tindakan operasi caesar. Metode yang digunakan yaitu Naive Bayes. Pada penelitian ini dataset dibagi menjadi data latih dan data uji menggunakan percentage split dengan persentase 5\%, 15\%, 25\%, 35\%, 45\%, 55\%, 65\%, 75\%, 85\%, dan $95 \%$. Dari penelitian yang dilakukan dihasilkan nilai akurasi yang kurang baik, dengan rata-rata terklasifikasi benar dan salah masing-masing $67.16 \%$ dan $32.84 \%$.

Penelitian yang dilakukan oleh Amalia et al., [6] bertujuan untuk pemilihan jenis persalinan yang tepat yang diharapkan dapat meminimalisir resiko kematian ibu serta bayi yang dilahirkan. Metode yang digunakan yaitu Nä̈ve Bayes dan Nä̈ve Bayes menggunakan Optimize Weights (PSO). Pada penelitian ini dilakukan dengan dua kali percobaan. Pada percobaan pertama untuk prediksi proses persalinan menggunakan algoritma Nä̈ve Bayes dihasilkan nilai akurasi sebesar 94\% dengan nilai AUC 0.96. Pada percobaan kedua untuk prediksi proses persalinan menggunakan algoritma Naïve Bayes dengan Optimize Weights (PSO) terdapat peningkatan nilai akurasi sebesar 4\%, yaitu menjadi 98\% dengan nilai AUC 1.000 .

Penelitian yang dilakukan oleh Shahar [8] bertujuan untuk mengetahui indikator apa saja yang membuat persalinan dapat dijalankan secara. Metode yang digunakan adalah Decision Tree. Adapun atribut dari dataset yang diteliti yaitu riwayat diabetes, tekanan darah, gawat janin, posisi bayi, jalan lahir, dan pinggul sempit. Dari penelitian yang dilakukan didapatkan hasil bahwa gawat janin merupakan atribut yang berdampak paling besar dalam indikator seseorang harus melakukan persalinan secara caesar, karena menempati posisi rote node. Adapun posisi bayi merupakan indikator paling kecil dalam seseorang harus melakukan persalinan secara caesar.

Penelitian yang dilakukan oleh Amalia \& Evicienna [9] bertujuan untuk penentuan proses melahirkan ibu dengan menggunakan tiga metode data mining, yaitu C4.5, Neural Network, dan Nä̈ve Bayes. Dari penelitian yang dilakukan didapatkan hasil bahwa metode Nä̈ve Bayes menghasilkan akurasi terbesar jika dibandingkan dengan metode C4.5 dan Neural Network, dengan akurasi $94 \%$ dan AUC 0.971. Adapun akurasi dari metode Neural Network dan C4.5 masing-masing sebesar 93\% dan 90\% dengan nilai AUC 0.962 dan 0.817. Dari nilai AUC yang didapatkan disimpulan bahwa metode Nä̈ve Bayes dan Neural Network termasuk dalam kategori sangat baik karena nilai AUC berada direntang 0.900-1.000. Sementara metode C4.5 masuk dalam kategori baik.

Penelitian yang dilakukan oleh Ali et al., [18] bertujuan untuk mempermudah Lembaga Penjamin Mutu Pendidikan yang mengalami kerumitan dalam memastikan kelayakan guru bersertifikasi menggunakan Neural Network dan optimasi Particle Swarm Optimation untuk memastikan kelayakan guru. Penelitian dilakukan dengan dua kali percobaan. Percobaan pertama untuk kelayakan pemberian sertifikasi guru menggunakan Neural Network dihasilkan nilai akurasi sebesar $79.65 \%$ dengan nilai AUC 0.874. Sedangakan pada percobaan kedua menggunakan Neural Network dan Particle Swarm Optimization menghasilkan akurasi $80.80 \%$ dan AUC sebesar 0.877. Dari dua percobaan yang dilakukan terdapat penambahan nilai akurasi sebesar $1.25 \%$ dengan menggunakan optimasi Particle Swarm Optimization.

Penelitian yang dilakukan oleh Hidayatulloh et al., [19] bertujuan untuk klasifikasi sel tunggal Pap Smear dalam mengidentifikasi awal keberadaan Human Pappiloma Virus (HPV) yang menyebabkan kanker servik. Metode yang digunakan adalah Nä̈ve Bayes dan Particle Swarm Optimization. Pada penelitian yang dilakukan dihasilkan nilai akurasi $95.70 \%$ untuk klasifikasi normal dan abnormal paling tinggi dari percobaan data latih berjumlah 826 (90\% dari 917 data) dan data testing 92 (10\% dari 917 data). Sedangkan nilai akurasi sebesar $62.67 \%$ untuk klasifikasi kelas 1 sampai kelas 7 nilai paling tinggi dari percobaan data latih 724 (80\% dari 917 data) dan data uji 183 (20\% dari 917 data).

Pada penelitian ini, penulis melakukan optimasi atribut klasifikasi penentuan penanganan persalinan Caesar menggunakan Neural Network dan Particle Swarm Optimization. Pada penelitian kali ini, perbedaan dengan penelitian yang pernah dilakukan di atas adalah menggunakan dataset 
sama dengan metode yang tidak sama juga metode sama dengan dataset yang tidak sama dari penelitian sebelumnya.

\section{Metode Penelitian}

Pada penelitian ini metode penelitian yang digunakan adalah eksperimen dan tahapan dalam penelitian ini seperti pada Gambar 1.

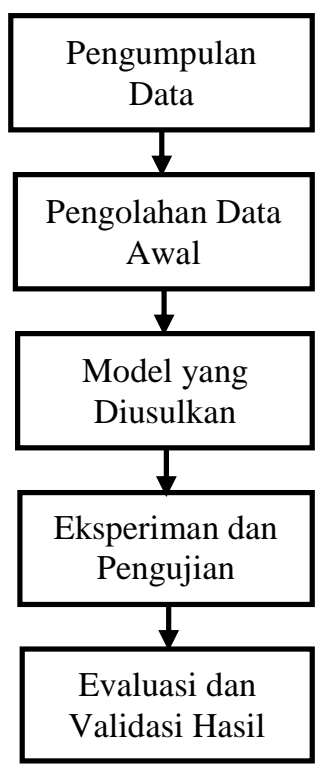

\section{Gambar 1. Tahapan Penelitian}

\subsection{Pengumpulan Data}

Pada penelitian ini penulis menggunakan dataset Caesarian Section Classification dari website UCI Machine Learning Repository yang dipublikasikan pada tahun 2018. Dataset terdiri dari 80 data pasien caesarian, terdiri dari lima atribut yang merupakan variabel paling berpengaruh pada masalah persalinan caesar yaitu Age, Delivery number, Delivery time, Blood of Pressure, Heart Problem dan satu label Caesarian. Deskripsi dari dataset Caesarian Section Classification seperti pada Tabel 1.

Tabel 1. Spesifikasi Dataset Caesarian Section Classification

\begin{tabular}{ll}
\hline \multicolumn{1}{c}{ Atribut } & \multicolumn{1}{c}{ Deskripsi } \\
\hline Age & numerik \\
\hline Delivery number & numerik \\
\hline Delivery time & timely, premature, latecomer \\
\hline Blood of Pressure & low, normal, high \\
\hline Heart Problem & apt, inept \\
\hline Caesarian & No, Yes \\
\hline
\end{tabular}

Dari 80 data pasien caesarian dalam dataset, terdiri dari 34 pasien tidak menjalani persalinan secara caesar dan sisanya yaitu 46 pasien menjalani persalinan secara caesar.

\subsection{Pengolahan Data Awal}

Untuk pengembangan dan pengujian model yang digunakan, data akan dibagi menjadi data latih dan data uji menggunakan Split Validation dari total 80 data pasien caesarian. Adapun besaran dari data latih yaitu $80 \%$ dan data uji yaitu $20 \%$. Data latih digunakan untuk pengembangan model dan data uji untuk pengujian model. Dataset yang sudah dibagi dapat langsung diolah dengan 
menggunakan model yang sudah ditentukan akan menghasilkan nilai yang dapat menjadi indikator seberapa baik model yang digunakan.

Namun untuk proses data mining menggunakan metode Neural Network terdapat proses perkalian antara input dengan bobot maka sebaiknya data yang ada tidak memiliki nilai nol. Pada dataset yang digunakan terdapat tiga atribut yang nilai yang direpresentasikan dengan nilai nol, yaitu Delivery Time, Blood of Pressure, dan Heart Problem. Maka data akan ditransformasikan menjadi nilai yang bisa diolah dengan Neural Network.

Berikut adalah hasil transformasi untuk atribut yang sudah ditransformasikan seperti pada Tabel 2.

Tabel 2. Transformasi Nilai

\begin{tabular}{cll}
\hline No & \multicolumn{1}{c}{ Atribut } & \multicolumn{1}{c}{ Nilai } \\
\hline 1 & Age & $22,26,28,27,32,36,33,23,20,29,25,37,24,18,30,40,31,19,21,35,17,38$ \\
\hline 2 & Delivery Number & $1,2,3,4$ \\
\hline \multirow{2}{*}{ Delivery Time } & $1=$ timely \\
& $2=$ premature \\
& $3=$ latecomer \\
& & $1=$ low \\
4 & \multirow{2}{*}{ Blood of Pressure } & $2=$ normal \\
& & $3=$ high \\
\hline \multirow{2}{*}{5} & \multirow{2}{*}{ Heart Problem } & $1=$ apt \\
& & $2=$ inept \\
\hline
\end{tabular}

\subsection{Model yang Diusulkan}

Model yang digunakan penulis dalam penelitian ini yaitu Neural Network dan Particle Swarm Optimization. Perancangan algoritma pada penelitian ini seperti pada Gambar 2.

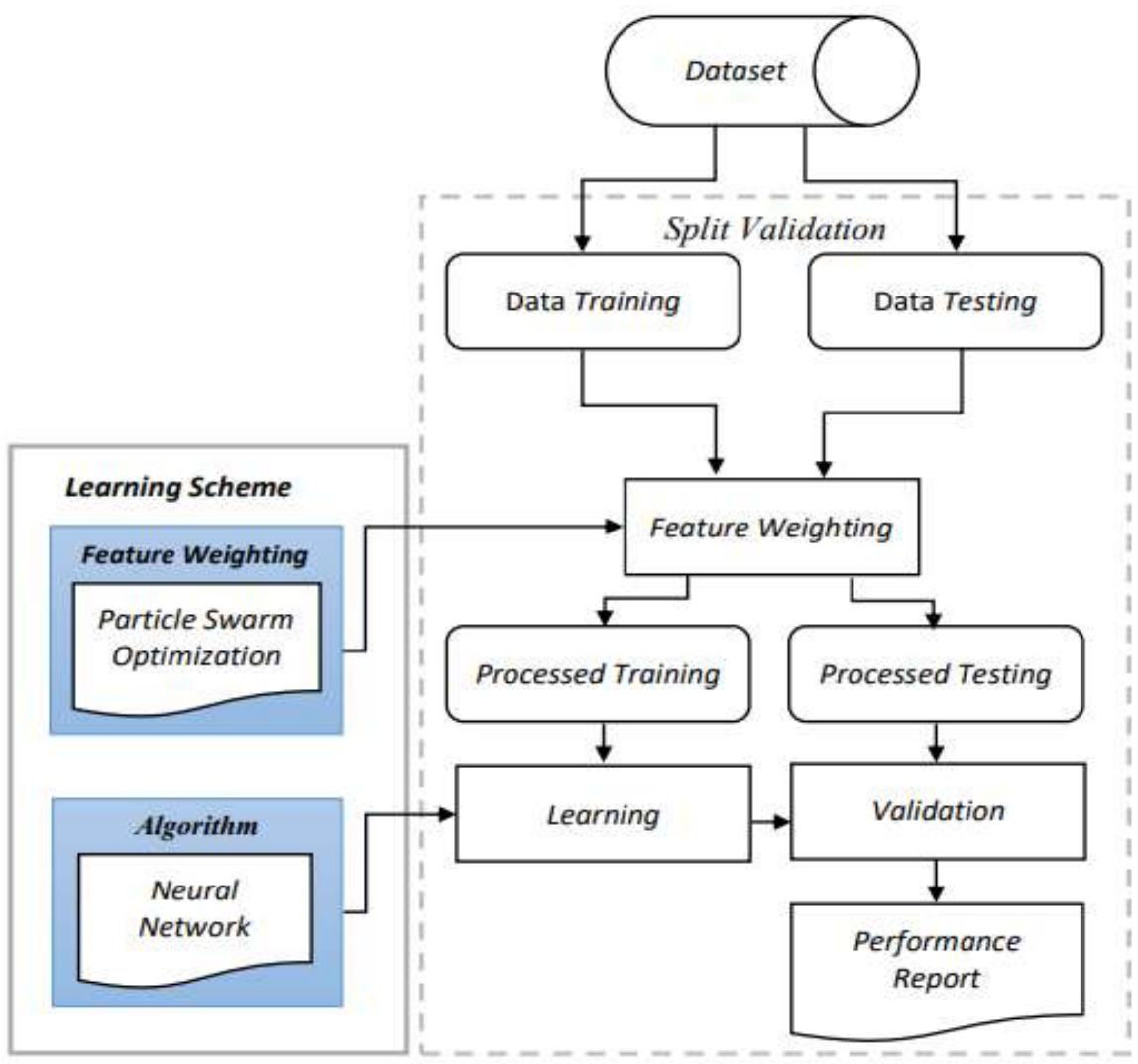

Gambar 2. Model yang Diusulkan 


\subsection{Eksperimen dan Pengujian Model}

Pada tahap eksperimen dan pengujian model, akan dilakukan eksperimen menggunakan sebuah perangkat lunak pada model yang selanjutnya akan dilakukan pemrosesan menggunakan metode yang sudah ditentukan di atas. Eksperimen yang dilakukan penulis kali ini dilakukan pada Caesarian Section Classification Dataset, selanjutnya dataset akan dibagi menjadi data latih dan data uji. Metode split digunakan untuk membagi data menjadi data latih dan data uji. Selanjutnya implementasikan metode optimasi dengan Particle Swarm Optimization guna mengoptimasi bobot pada masing-masing atribut, yang diharapkan dapat memaksimalkan nilai akurasi yang dihasilkan. Confusion Matrix dan Area Under Curve (AUC) akan digunakan pada tahap evaluasi dan validasi model.

Pada penelitian ini eksperimen dan uji model dilakukan dengan menggunakan bantuan software RapidMiner versi 9.4.1.0. Adapun spesifikasi komputer yang digunakan seperti pada Tabel 3.

Tabel 3. Spesifikasi Komputer

\begin{tabular}{ll}
\hline Processor & Intel Core i3 2.00 Ghz \\
\hline RAM & $8 \mathrm{~GB}$ \\
\hline Harddisk & $1 \mathrm{~TB}$ \\
\hline Operating System & Windows 10 Pro \\
\hline Application & RapidMiner Studio 9.4.1.0 \\
\hline
\end{tabular}

\subsection{Evaluasi dan Validasi Model}

Pada tahap evaluasi dan validasi model akan dilakukan evaluasi model menggunakan confusion matrix yang digunakan untuk pengukuran kinerja model yang digunakan. Kinerja yang diukur yaitu Area Under Curve (AUC). Validasi model yang dilakukan yaitu dengan menggunakan Split Validation dimana dataset akan dibagi menjadi data latih dan data uji. Metode Neural Network dan Neural Network dengan Particle Swarm Optimization akan diukur lalu kinerja keduany akan dibandingkan.

\section{Hasil dan Pembahasan}

Penerapan metode Neural Network dan Particle Swarm Optimization pada Caesarian Section Classification Dataset bertujuan guna mendapatkan akurasi yang diharapkan bisa meningkatkan akurasi pada klasifikasi pasien caesar dari penelitian-penelitian yang telah dilakukan [17], [3], dan [12]. Pada eksperimen akan terlihat hasil akurasi, baik itu akurasi yang optimal ataupun tidak. Eksperimen dilakukan sebanyak dua kali, yaitu eksperimen pertama menggunakan Neural Network lalu eksperimen kedua menggunakan Neural Network dan Particle Swarm Optimization.

\subsection{Hasil Eksperimen Metode Neural Network}

Pada tahapan eksperimen ini akan dipaparkan hasil dari eksperimen menggunak Neural Network dengan evaluasi menggunakan Split Validation. Sesudah dilakukan pengujian model, maka akan didapatkan hasil pada Tabel 4 berikut.

Tabel 4. Hasil Akurasi Neural Network

\begin{tabular}{cccccc}
\hline Learning rate & epoch & Momentum & Split Ratio & Akurasi & AUC \\
\hline 0.7 & 1000 & 0.9 & $60: 40$ & $62.50 \%$ & 0.655 \\
\hline 0.7 & 1000 & 0.9 & $70: 30$ & $70.83 \%$ & 0.629 \\
\hline 0.7 & 1000 & 0.9 & $80: 20$ & $62.50 \%$ & 0.651 \\
\hline 0.7 & 1000 & 0.9 & $90: 10$ & $87.50 \%$ & 1.000 \\
\hline
\end{tabular}

Pada Tabel 4 di atas didapatkan bahwa model Neural Network dengan perbanding data latih dan data uji sebesar 90:10 memiliki nilai akurasi paling tinggi yaitu 87.50\% dengan nilai AUC 1.000. 
Tabel 5. Confusion Matrix Neural Network

\begin{tabular}{cccc}
\hline & True No & True Yes & Class precision \\
\hline Pred. No & 2 & 0 & $100 \%$ \\
\hline Pred. Yes & 1 & 5 & $83.33 \%$ \\
\hline Class Recall & $66.67 \%$ & $100 \%$ & \\
\hline
\end{tabular}

Dari hasil confusion matrix pada Tabel 5 di atas, maka dapat dihitung nilai akurasi sebagai berikut :

$$
\begin{aligned}
\text { Accuracy } & =\frac{\mathrm{TP}+\mathrm{TN}}{\mathrm{TP}+\mathrm{TN}+\mathrm{FP}+\mathrm{FN}} \times 100 \% \\
& =\frac{5+2}{5+2+1+0} \times 100 \% \\
& =87.50 \%
\end{aligned}
$$

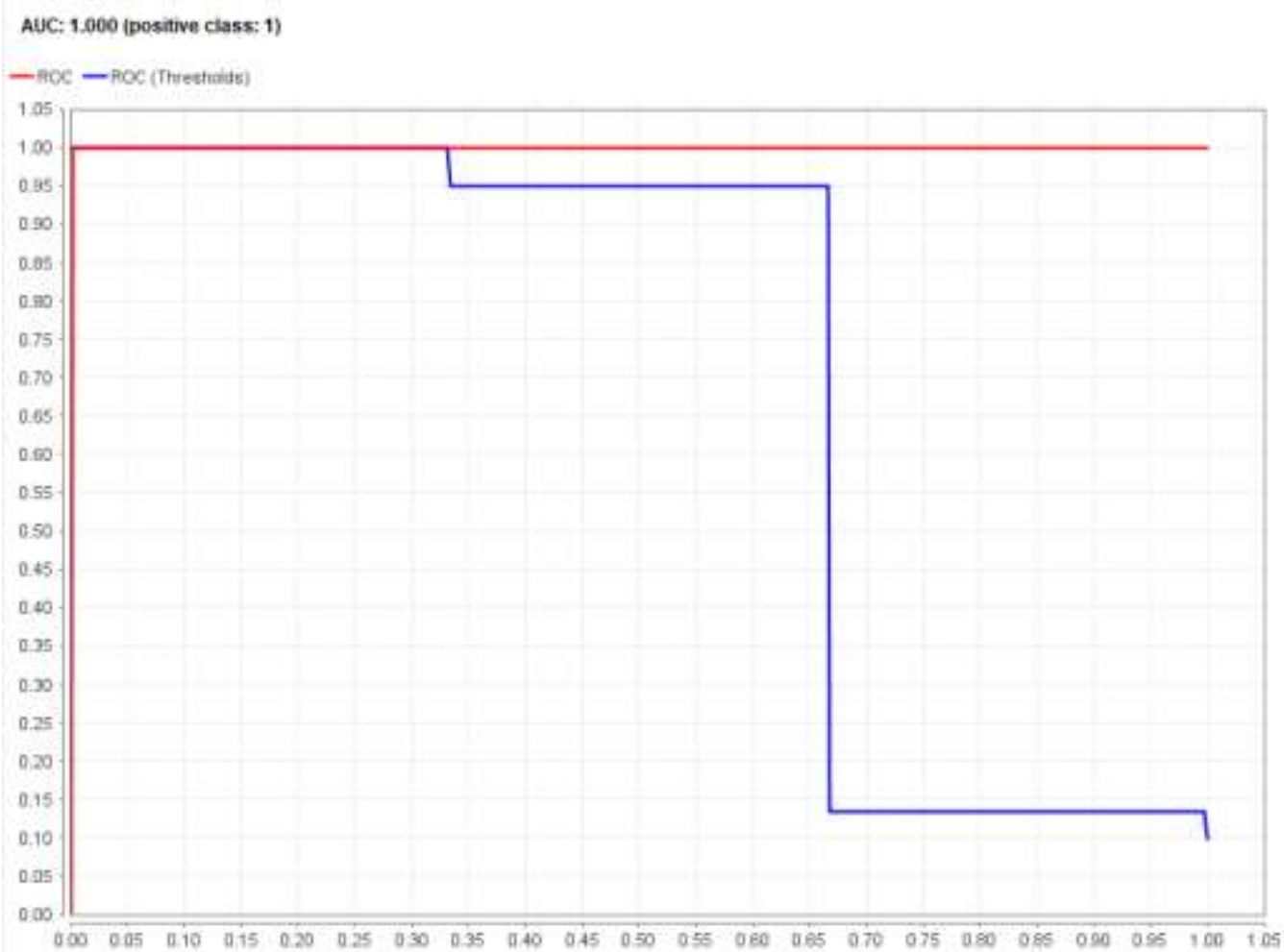

Gambar 3. Kurva ROC Neural Network

Pada pengujian metode Neural Network juga didapatkan kurva ROC seperti pada Gambar 3 di atas, menghasilkan AUC sebesar 1.000, nilai AUC tersebut dikategorikan sebagai Excellent Classification karena berada pada rentang nilai 0.900-1.000.

\subsection{Hasil Eksperimen Metode Neural Network berbasis Particle Swarm Optimization}

Particle Swarm Optimization digunakan untuk melakukan optimasi bobot terhadap atribut dari masing-masing atribut pada Caesarian Section Classification Dataset. Perhitungan dilakukan menggunakan RapidMiner. Adapun hasil pembobotan atribut oleh Particle Swarm Optimization menggunakan RapidMiner adalah seperti pada Tabel 6. 
Tabel 6. Hasil Pembobotan Particle Swarm Optimization

\begin{tabular}{ll}
\hline \multicolumn{1}{c}{ Attribute } & Weight \\
\hline Age & 0.528 \\
\hline Delivery Number & 1 \\
\hline Delivery Time & 0.976 \\
\hline Blood of Pressure & 0 \\
\hline Heart Problem & 1 \\
\hline
\end{tabular}

Dari hasil eksperimen metode Neural Network dan optimasi Particle Swarm Optimization didapatkan hasil pembobotan setiap atribut. Pada Tabel 6 di atas terdapat satu atribut yang memiliki bobot nol yaitu Blood of Pressure, yang berarti atribut tersebut tidak memilik pengaruh terhadap penelitian yang dilakukan.

Tabel 7. Hasil Akurasi Neural Network berbasis Particle Swarm Optimization

\begin{tabular}{cccccc}
\hline Learning rate & epoch & Momentum & Split Ratio & Akurasi & AUC \\
\hline 0.7 & 1000 & 0.9 & $60: 40$ & $75.00 \%$ & 0.798 \\
\hline 0.7 & 1000 & 0.9 & $70: 30$ & $79.17 \%$ & 0.814 \\
\hline 0.7 & 1000 & 0.9 & $80: 20$ & $93.75 \%$ & 0.913 \\
\hline 0.7 & 1000 & 0.9 & $90: 10$ & $88.90 \%$ & 0.902 \\
\hline
\end{tabular}

Pada Tabel 7 di atas didapatkan bahwa model Neural Network dan Particle Swarm Optimization dengan perbanding data latih dan data uji sebesar 80:20 memiliki nilai akurasi paling tinggi yaitu 93.75\% dengan nilai AUC 0.913.

Tabel 8. Confusion Matrix Neural Network berbasis Particle Swarm Optimization

\begin{tabular}{cccc}
\hline & True No & True Yes & Class precision \\
\hline Pred. No & 7 & 1 & $87.50 \%$ \\
\hline Pred. Yes & 0 & 8 & $100 \%$ \\
\hline Class Recall & $100 \%$ & $88.89 \%$ & \\
\hline
\end{tabular}

Dari hasil confusion matrix pada Tabel 8 di atas, maka dapat dihitung nilai akurasi sebagai berikut :

$$
\begin{aligned}
\text { Accuracy } & =\frac{\mathrm{TP}+\mathrm{TN}}{\mathrm{TP}+\mathrm{TN}+\mathrm{FP}+\mathrm{FN}} \times 100 \% \\
& =\frac{8+7}{8+7+0+1} \times 100 \% \\
& =93.75 \%
\end{aligned}
$$




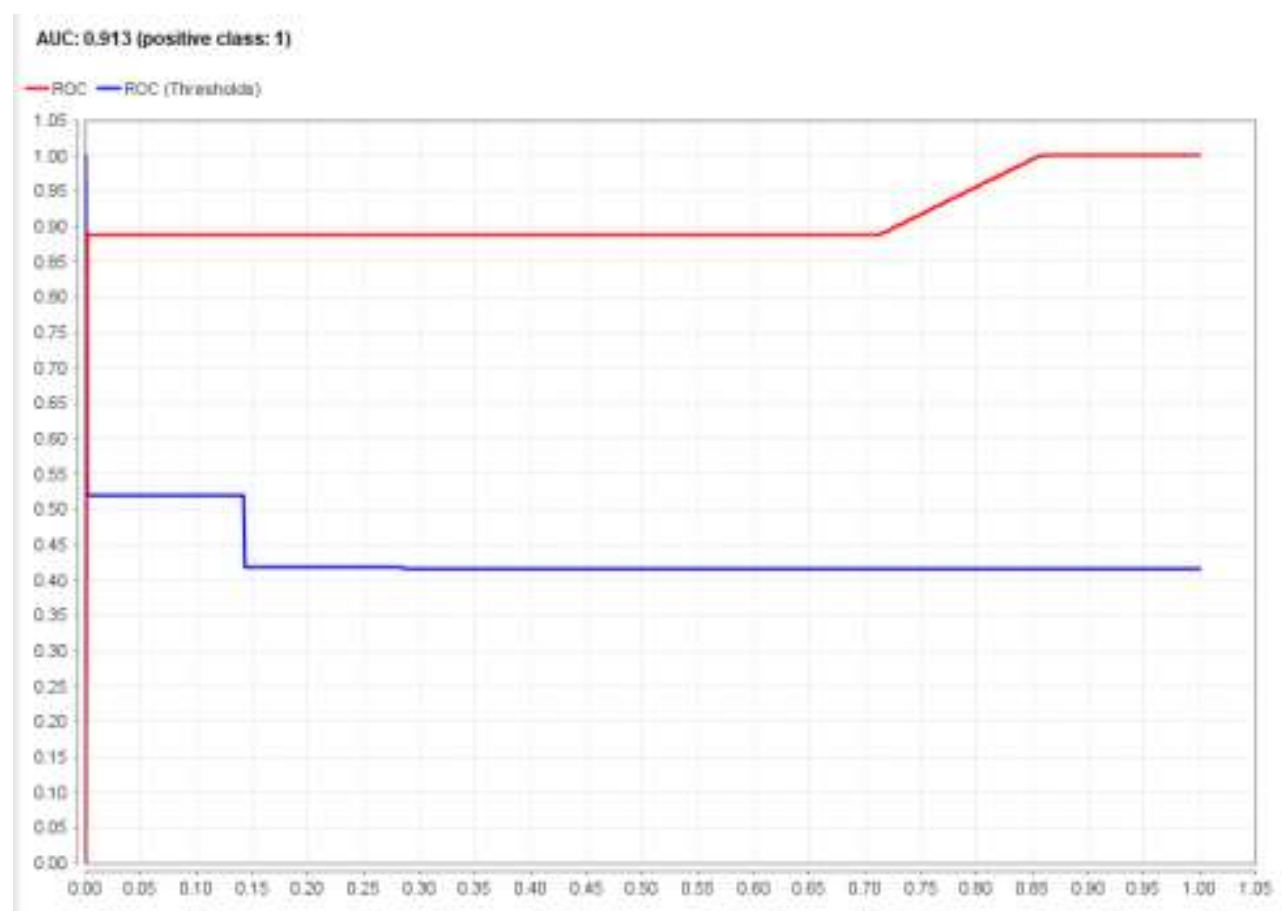

Gambar 4. Kurva ROC Neural Network berbasis Particle Swarm Optimization

Pada pengujian metode Neural Network dengan Particle Swarm Optimization juga diperoleh Kurva ROC seperti pada Gambar 4 di atas, dengan nilai AUC sebesar 0.913 dan dikategorikan sebagai Excellent Classification karena berada pada rentang nilai 0.900-1.000.

\subsection{Perbandingan Hasil Pengujian}

Berdasarkan pada penelitian yang penulis telah laksanakan, penulis akan melakukan evaluasi guna mengetahui kenaikan akurasi dari pengujian klasifikasi yang dihasilkan menggunakan metode Neural Network lalu Neural Network dan Particle Swarm Optimization. Berikut merupakan perbandingan dari nilai akurasi dari pemodelan Neural Network dengan Neural Network dan Particle Swarm Optimization.

\section{Perbandingan Hasil Pengujian}

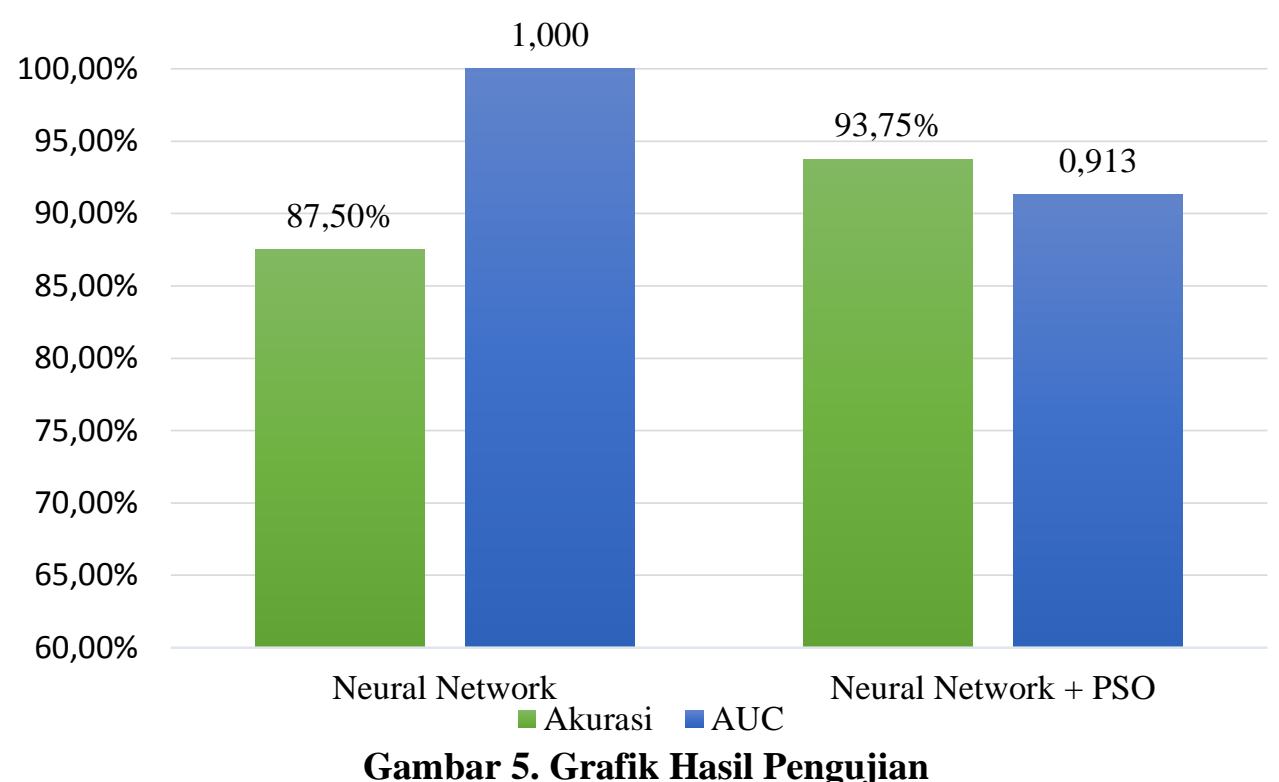


Pada Gambar 5 di atas terlihat jika hasil pengujian Neural Network mengalami peningkatan nilai akurasi sebesar $6.25 \%$ setelah pembobotan dengan Particle Swarm Optimization, maka dapat disimpulkan jika penggunaan Particle Swarm Optimization bisa meningkatkan nilai akurasi dari klasifikasi penanganan pasien caesar.

\section{Kesimpulan}

Pada penelitian ini telah dilakukan penerapan algoritma klasifikasi Neural Network dan metode optimasi Particle Swarm Optimization pada Caesarian Section Classification Dataset. Optimasi bobot pada Caesarian Section Classification Dataset menggunakan Particle Swarm Optimization menghasilkan peningkatan akurasi dan performa. Hasil perhitungan menggunakan metode Neural Network yang diimplementasikan pada Caesarian Section Classification Dataset memperoleh akurasi sebesar $87.50 \%$ dengan nilai AUC sebesar 1.000. Setelah dilakukan optimasi menggunakan Particle Swarm Optimization untuk pembobotan atribut nilai akurasi mengalami peningkatan menjadi $93.75 \%$ dengan nilai AUC 0.913. Terlihat bahwa nilai akurasi pada Caesarian Section Classification Dataset menggunakan Neural Network mengalami peningkatan sebesar $6.25 \%$ setelah dilakukan pembobotan atribut menggunakan Particle Swarm Optimization. Penggunaan metode Neural Network dan Particle Swarm Optimization pada Caesarian Section Classification Dataset terbukti memiliki peningkatan nilai akurasi dibandingkan penelitian sebelumnya. Maka dapat penulis disimpulkan jika penggunaan Particle Swarm Optimization dapat menghasilkan peningkatan akurasi pada metode Neural Network pada dataset persalinan caesar.

\section{Referensi}

[1] World Health Organization, "Maternal mortality: level and trends 2000 to 2017," 2019. [Online]. Available: https://www.who.int/reproductivehealth/publications/maternal-mortality2000-2017/en/.

[2] A. Pribadi, "Program Akselerasi Penurunan Angka Kematian Ibu POGI Jabar Zero Mother Mortality Preeclampsia (ZOOM)," Indones. J. Obstet. Gynecol. Sci., vol. 1, no. 1, pp. 1-5, 2018, doi: 10.24198/obgynia.v1n1.80.

[3] M. J. Shidiq, S. Rahayu, and F. S. Nugraha, "Klasifikasi Diagnosis Melahirkan Dengan Metode Sesar Menggunakan Neural Network," J. Pilar Nusa Mandiri, vol. 15, no. 2, pp. 157162, 2019, doi: 10.33480/pilar.v15i2.602.

[4] S. Diana, E. Mail, and Z. Rufaida, Buku Ajar Asuh Kebidanan Persalinan Dan Bayu Baru Lahir. Surakarta: CV OASE GROUP, 2019.

[5] N. Sihombing, I. Saptarini, and D. S. K. Putri, "The Determinants of Sectio Caesarea Labor in Indonesia ( Further Analysis of Riskesdas 2013)," J. Kesehat. Reproduksi, vol. 8, no. 1, pp. 63-75, 2017, doi: 10.22435/kespro.v8i1.6641.63-75.

[6] H. Amalia, A. B. Pohan, and S. Masripah, "Penerapan Feature Weighting Optimized Pada Naïve Bayes Untuk Prediksi Proses Persalinan," J. Pilar Nusa Mandiri, vol. 15, no. 1, pp. 1520, 2019, doi: 10.33480/pilar.v15i1.3.

[7] S. R. Arman, "Faktor-faktor yang Berhubungan Dengan Pemilihan Metode Persalinan Sectio Caesarea di Rumah Sakit Agung Jakarta Periode November 2016-Oktober 2017,” 2017.

[8] N. R. Shahar, "Analisis Faktor-Faktor Penyebab Proses Persalinan Secara Caesar Menggunakan Algoritma ID3 Dengan Metode Decision Tree," 2016.

[9] H. Amalia and Evicienna, "Komparasi Metode Data Mining Untuk Penentuan Proses Persalinan Ibu Melahirkan," J. Sist. Inf., vol. 13, no. 2, p. 103, 2017, doi: 10.21609/jsi.v13i2.545.

[10] Y. Ramdhani, S. Susanti, M. F. Adiwisastra, and S. Topiq, "Penerapan Algoritma Neural Network Untuk Klasifikasi Kardiotokografi," J. Inform., vol. 5, no. 1, pp. 43-49, 2018, doi: 10.31311/ji.v5i1.2832.

[11] R. Sanjaya and D. Puspitasari, "Noise Reduction through Bagging on Neural Network Algorithm for Forest Fire Estimates," 2018 6th Int. Conf. Cyber IT Serv. Manag., no. CITSM, pp. 1-5, 2018, doi: 10.1109/CITSM.2018.8674287. 
[12] A. Herliana, T. Arifin, S. Susanti, and A. B. Hikmah, "Feature Selection of Diabetic Retinopathy Disease Using Particle Swarm Optimization and Neural Network," no. CITSM, pp. 2016-2019, 2018.

[13] M. R. Lubis, "Metode Hybrid Particle Swarm Optimization - Neural Network Backpropagation Untuk Prediksi Hasil Pertandingan Sepak Bola," J-SAKTI (Jurnal Sains Komput. dan Inform., vol. 1, no. 1, p. 71, 2017, doi: 10.30645/j-sakti.v1i1.30.

[14] M. Ary, "Aplikasi Prediksi Banjir Metode Fuzzy Logic, Hasil Algoritma Spade dam Algoritma PSO," Konf. Nas. Ilmu Sos. Teknol., pp. 342-348, 2017.

[15] T. Arifin and D. Ariesta, "Prediksi Penyakit Ginjal Kronis Menggunakan Algoritma Naive Bayes Classifier Berbasis Particle Swarm Optimization,” vol. 13, no. 1, pp. 26-30, 2019.

[16] P. Erdogmus, "Introductory Chapter: Swarm Intelligence and Particle Swarm Optimization," Intech, p. 9, 2018, doi: 10.1016/j.colsurfa.2011.12.014.

[17] G. Abdurrahman and J. T. Wijaya, "Analisis Klasifikasi Kelahiran Caesar Menggunakan Algoritma Naive Bayes," JUSTINDO (Jurnal Sist. dan Teknol. Inf. Indones., vol. 4, no. 2, pp. 46-51, 2019, doi: 10.32528/justindo.v4i2.2616.

[18] K. P. Wicaksono, M. A. Soeleman, and R. A. Pramunendar, "Optimasi Particle Swarn Optimization (PSO) Pada Algoritma Klasifikasi Neural Network (NN) Dalam Penentuan Kelayakan Pemberian Sertifikasi Guru,” vol. 14, pp. 49-59, 2018.

[19] T. Hidayatulloh, A. Herliana, and T. Arifin, "Klasifikasi Sel Tunggal Pap Smear Berdasarkan Analisis Fitur Berbasis Naïve Bayes Classifier Dan Particle Swarm Optimization," vol. 4, no. 2, pp. 186-193, 2016. 